\title{
THE PERFORMANCE OF FOREIGN-OWNED BANKS IN HOST COUNTRY ECONOMIES
}

\section{Tereza Fišerová, Petr Teplý, David Tripe*}

\begin{abstract}
:
The paper deals with the phenomenon of foreign bank ownership, which is prevalent in the countries of Central, Eastern and South Eastern European region as well as in New Zealand. Using a sample of 17 countries and filtering out more than 140 domestically operating foreign-owned banks, we examine the determinants of their performance in relation to host country conditions over the period of seven years between 2005 and 2011. Based on our knowledge, we use the largest data set in this respect compared to other researchers. Using system GMM and fixed effects models, we reveal that macroeconomic fundamentals of the host country affect the foreign-owned banks' performance but do not suffice in explaining it fully. This result points out that sound banks with higher operational efficiency operating in growing economies with low inflation rate tend to perform better than their peers.
\end{abstract}

Keywords: banks and banking, bank performance measurement, fixed effects model, foreign ownership, generalized method of moments.

JEL Classification: G21, L25

\section{Introduction}

Over the last 20 years, the extent of foreign ownership in individual countries' banking system has increased very substantially. Back in 1996, when the Australian-owned Westpac Banking Corporation acquired the New Zealand-owned Trust Bank New Zealand, to make the combined assets of the New Zealand banking system $99 \%$ foreignowned, New Zealand was a very unusual case. Studies that looked at the performance of foreign-owned banks, such as Claessens et al. (2001) or Williams (1998) thus mostly identified relatively small groups of banks as foreign-owned, rather than banks that comprised the major part of host country banking systems. Even where there was a study of a predominantly foreign-owned banking system, such as New Zealand (To and Tripe, 2002), it was possible that the results obtained might be a reflection of country specific idiosyncratic factors, such as the New Zealand case where most foreign-owned bank

Tereza Fišerová, Institute of Economic Studies, Faculty of Social Sciences, Charles University in Prague, Czech Republic (tereza.fiserova1@gmail.com);

Petr Teplý, Department of Banking and Insurance, Faculty of Finance and Accounting, University of Economics, Prague, Czech Republic, Institute of Economic Studies, Faculty of Social Sciences, Charles University in Prague, Czech Republic (petr.teply@vse.cz);

David Tripe, School of Economics and Finance, Massey University, Palmerston North, New Zealand (d.w.tripe@massey.ac.nz).

Financial support from the Czech Science Foundation (Project No. GACR 14-02108S) and by University of Economics in Prague (Project No. VŠE IP100040) is gratefully acknowledged. Authors are also thankful for valuable comments by Ms. Yael Roshwalb. 
assets were Australian-owned, and where the foreign-owned banks were acquired going concerns rather than being greenfield operations.

By 2010, foreign ownership of banks was a relatively more commonplace phenomenon, often driven by rescues and recapitalisations of struggling domestic banks in those host country markets which had been subject to some sort of economic shock. We thus saw significant foreign stakes being acquired in banks, particularly in the countries of Central and Eastern Europe (CEE) as they reformed and restructured their banking systems in the late 1990s and early 2000s (Bonin et al., 2005a, 2005b; Berger, 2007a). This paper can thus look at the performance of foreign-owned banks without our results being subject to the potential peculiarities of the sample employed, and for the CEE countries, with a longer period of banks being under foreign ownership. On a related note, Stavárek $(2005 ; 2006)$ concludes that differences in banking efficiency exist within CEE and the level of efficiency may be explained mainly by banking specific characteristics.

What should we expect for the performance of foreign-owned banks in host country markets? The primary expectation, from the work of Demirgüç-Kunt and Huizinga (1999) and Claessens et al. (2001), is that in less developed countries, foreign banks will earn higher interest margins and profits, but lower margins and profits in more developed countries. On the other hand, there is a reasonable case to suggest that foreign-owned firms may face difficulties in establishing businesses outside their home countries: this is the "liability of foreignness", described by Zaheer and Mosakowski (1997) and Miller and Parkhe (2002). The lack of public familiarity with their brands and the lack of an established customer base in the host country community mean that new entrant banks face considerable challenges in building a critical mass to develop a viable banking business.

The other side of the liability of foreignness is a countervailing incumbency effect, which suggests that the disadvantage of foreign ownership dissipates through time. To and Tripe (2002) found evidence that foreign owned banks with a longer experience of being in New Zealand were larger and more profitable than recent arrivals. Subsequent research by Tripe et al. (2009) found that long established foreign-owned banks were not even identified as foreign owned. In a similar vein, Guillen and Tschoegl (2000) found that incumbency permitted a Spanish bank to pursue an acquisition and market penetration strategy in Latin America that was more aggressive (and successful) than banks with weaker ties to the region.

We would expect this to be an issue for much of the foreign expansion into the CEE countries, where in many cases, foreign bank investors have acquired locally-owned banks and retained existing name, branch network and management (Popov and Udell, 2010; Mejstř́k et al., 2008). For example, in the Czech Republic, major banks include Česká spořitelna, ČSOB and Komerční banka, which are owned by the Austrian Erste Group, Belgian bank KBC, and French banking group Societe Generale, respectively. We would expect such banks to earn higher margins and to be more profitable than greenfields operations.

Much of the previous research in this area (e.g. Bonin et al. 2005a, 2005b) has used the techniques of multivariate efficiency analysis such as Stochastic Frontier Analysis (SFA) or Data Envelopment Analysis (DEA) or Meta-Regression Analysis. The first two of these methods are the most popular, as documented by Berger and Humphrey (1997), or more recently by Iršová and Havránek (2010). A number of challenges arise with cross-country studies, however (see Berger, 2007b), and there would also have to be 
doubts as to whether one could legitimately assume the existence of a common frontier. The problems with cross-country studies are exacerbated in this case because we are looking at a relatively diverse range of countries, although it is possible that we may pursue this approach in future research. Not all research on bank performance has been based on multivariate efficiency analysis, however, and alternative econometric approaches have been used in recent times by, for example, Athanasoglou et al. (2008), and Albertazzi and Gamborta (2009 and 2010). This provides a useful precedent for our not using efficiency methods.

The paper is organized as follows: The next section introduces the dataset and variables used for analysis. Section 3 discusses our methods in greater detail. In Section 4 we test a hypothesis whether economic fundamentals in the host country influence directly the performance of foreign-owned banks in the host country. Moreover, this section summarizes our key results and findings. Finally, Section 5 concludes the paper and states final remarks.

\section{Data Analysis}

\subsection{Dataset}

For the general selection of countries whose banks and financial sectors are analysed, the following criteria were applied: (i) country is either a member of OECD or geographically belongs to Europe; and (ii) total share of assets within the country's banking sector owned by a foreign entity exceeds $60 \%$ as of the end of 2010 . The final dataset is a balanced panel covering the seven-year period from 2005 to 2011. Only those banks that are majority owned by a foreign entity enter the analysis. For the analysis, the type of owner entity does not matter and all types are included. The data availability enables us to study more than 140 banks (on average over 8 banks per country). Countries meeting the criteria and for which sufficient data was available are summarized in Table 1. Hong Kong is added to the dataset as it is an important international player with high foreign-ownership ratio and belongs, similarly to Luxembourg or New Zealand, to the high-income country group.

\section{Table 1 | List of Host Countries and Their ISO Code}

\begin{tabular}{|r|r|r|}
\hline Bosnia and Herzegovina : BA & Hungary : HU & New Zealand : NZ \\
\hline Bulgaria : BG & Ireland : IE & Poland : PL \\
\hline Croatia : HR & Latvia : LV & Romania : RO \\
\hline Czech Republic : CZ & Lithuania : LT & Serbia : RS \\
\hline Estonia : EE & Luxembourg : LU & Slovak Republic : SK \\
\hline Hong Kong : HK & Malta : MT \\
\hline
\end{tabular}

Source: Authors

The BankScope database is the primary data source, for the analysis, complemented by variety of other sources such as Bloomberg, the IMF, OECD iLibrary and World Bank databases, Eurostat and individual countries' national banks. Due to lower reliability of BankScope data in case of transition countries as suggested by Bonin, et al. (2005a), the 
dataset was thoroughly reviewed and cross-referenced with other authors and using more sources. For the analysis, five types of financial institutions (as categorized in the BankScope database) are considered: bank holdings $\&$ holding companies, commercial banks, cooperative banks, real estate \& mortgage banks, and savings banks. Thus, central banks, investment banks, leasing companies and other types of financial institutions are excluded from the sample. A bank is considered as foreign-owned if the total share of assets owned by a foreign entity (regardless of the type of the owner) is higher or equal to $50 \%$.

\section{Table 2 | Bank Specific Variables}

\section{Bank-specific variables}

\begin{tabular}{|c|c|c|}
\hline $\begin{array}{l}\text { Natural logarithm } \\
\text { of total assets }\end{array}$ & $\begin{array}{l}\text { Commonly used to approximate the size of a bank. The natural } \\
\text { logarithm helps smooth out large differences between individual } \\
\text { bank's total assets. }\end{array}$ & In_ta \\
\hline $\begin{array}{l}\text { Net loans to total } \\
\text { assets ratio }\end{array}$ & $\begin{array}{l}\text { Captures how large share of total assets is accounted for by the loan } \\
\text { portfolio and is considered a risk ratio. The expected sign of estimated } \\
\text { coefficient is unclear due to the fact that high ratios may negatively } \\
\text { affect liquidity while low ratios indicate lower interest income. }\end{array}$ & nlta \\
\hline $\begin{array}{l}\text { Loans to deposits } \\
\text { and short-term } \\
\text { funding ratio }\end{array}$ & $\begin{array}{l}\text { A liquidity measure which reflects the structure of the bank's balance } \\
\text { sheet and the balance of each bank's business model. }\end{array}$ & Ilstf \\
\hline $\begin{array}{l}\text { Loan loss reserves } \\
\text { to gross loans }\end{array}$ & $\begin{array}{l}\text { Represents the part of loan portfolio that is set aside for potential } \\
\text { charge-off and reflects the bank's asset quality. }\end{array}$ & Ilsgl \\
\hline Equity to total assets & $\begin{array}{l}\text { A measure of the bank's ability to meet its obligations and absorb } \\
\text { potential losses. As a low ratio can be a sign of insufficient capital and } \\
\text { a high ratio may indicate foregone investment opportunities, the } \\
\text { coefficient's sign is not clear. }\end{array}$ & eta \\
\hline Cost to income ratio & $\begin{array}{l}\text { Indicates the share of income consumed by operational costs and thus } \\
\text { reflects the operational efficiency. Therefore, a negative coefficient is } \\
\text { expected. }\end{array}$ & $\mathrm{Ci}$ \\
\hline $\begin{array}{l}\text { Loan impairment } \\
\text { charges to average } \\
\text { gross loans }\end{array}$ & $\begin{array}{l}\text { Measures the credit quality management by comparing the } \\
\text { impairment losses and the size of the loan portfolio. It is used as } \\
\text { a proxy for non-performing loans as data on this indicator were not } \\
\text { available. A negative sign for this asset quality measure is expected. }\end{array}$ & $n p l$ \\
\hline $\begin{array}{l}\text { Liquid assets to } \\
\text { deposits and short- } \\
\text { term funding ratio }\end{array}$ & $\begin{array}{l}\text { Another variable capturing the liquidity of a given bank. The expected } \\
\text { sign is again ambiguous as a high ratio may result in lost investment } \\
\text { opportunities; a low ratio may increase the bank's borrowing rates. }\end{array}$ & lastf \\
\hline
\end{tabular}

There are also several dummy variables among the bank-specific variables. These are: listing (dlist: $0=$ listed; 1 unlisted or delisted), bank owner type (down: 1 = bank; 0 = other institution or an individual) and type of bank (dcomm: commercial bank or bank holding; dcoop: 1 = cooperative bank; dsav: 1 = savings bank; 0 = real estate and mortgage bank).

\section{Variables}

We test a hypothesis whether economic fundamentals in the host country influence directly the performance of foreign-owned banks in the host country. The selection of variables entering the analysis is based on the works of Yi, et al. (2009), Heffernan and Fu (2010), 
and Miklaszewska and Mikolajczyk (2012). As dependent variables, three performance indicators were chosen: Return on average assets (ROAA), Return on average equity (ROAE), Net interest margin (NIM). The explanatory (independent) variables can be classified as bank-, banking sector- and country-specific. The following table lists variables of each of the group and provide a brief description.

Table 3 | Banking Sector and Host Country Specific Variables

\begin{tabular}{|l|l|c|}
\hline \multicolumn{2}{|c|}{ Banking sector specific variables } & nobanks \\
\hline $\begin{array}{l}\text { Number of finan- } \\
\text { cial institutions }\end{array}$ & Represents the size of the given banking sector. & $\begin{array}{l}\text { Approximates the concentration of the banking sector and is } \\
\text { computed from the data using individual bank's total assets market } \\
\text { share. In case HHI is higher than 1800 units, the banking sector is } \\
\text { considered highly concentrated, in case HHI is between 1000 and } \\
1800 \text { units, the sector is considered moderately concentrated, low } \\
\text { concentration is assigned to sectors with HHI lower than 1000. }\end{array}$ \\
\hline $\begin{array}{l}\text { Herfindahl- } \\
\text { Hirschman index }\end{array}$ & hhi \\
\hline $\begin{array}{l}\text { Banking assets } \\
\text { to GDP ratio }\end{array}$ & Indicates the penetration of the banking sector. \\
\hline
\end{tabular}

\begin{tabular}{|l|l|c|}
\hline \multicolumn{2}{|c|}{ Host country specific variables } & gdp \\
\hline $\begin{array}{l}\text { Real annual GDP } \\
\text { growth rate }\end{array}$ & The coefficient is expected to be positive when the rate is positive. \\
\hline $\begin{array}{l}\text { Annual inflation } \\
\text { rate }\end{array}$ & $\begin{array}{l}\text { Represents the year-on-year percentage increase in consumer price } \\
\text { index, the relation between bank performance and inflation is } \\
\text { expected negative. }\end{array}$ & infl \\
\hline $\begin{array}{l}\text { Annual unemploy- } \\
\text { ment rate }\end{array}$ & Should affect bank performance adversely. & unemp \\
\hline $\begin{array}{l}\text { Annual interest } \\
\text { rate }\end{array}$ & $\begin{array}{l}\text { Is approximated by ten-year government bond yield of each of the } \\
\text { selected countries. }\end{array}$ & bond \\
\hline
\end{tabular}

Note: The macroeconomic variables are lagged by one year in order to let the conditions get reflected in the financial statements of individual banks. There is also a time trend included in the regression.

\subsection{Descriptive Analysis}

We start the descriptive analysis by exploring the dependent variables - banks' performance measured by return on average assets and equity (ROAA, ROAE) and net interest margin (NIM). Figure 1 captures the mean of each of the dependent variables by bank type. In terms of ROAA and ROAE, cooperative and real estate and mortgage banks perform roughly the same; savings banks' performance on average is relatively the worst throughout the period. The opposite is true when NIM is used as a measure of performance and real estate and mortgage banks rank markedly the lowest. The right panel of the figure shows the evolution of ROAE by bank type in time from 2005 to 2011. A clear sharp decrease in performance is documented from 2008 to 2009 for all types of banks 
except for the commercial banks, where the lowest point (just positive) is documented as late as in 2010. The mean was, however, gradually going down from 2007 for this bank type, on average by $4.3 \%$ per year. Between 2010 and 2011, the trend turned and commercial banks report an average growth in performance measured by ROAE of $3.5 \%$.

Figure 1 | Mean Profitability by Bank Type (2005-2011)

\section{A: Mean ROAA, ROAE and NIM by bank type}

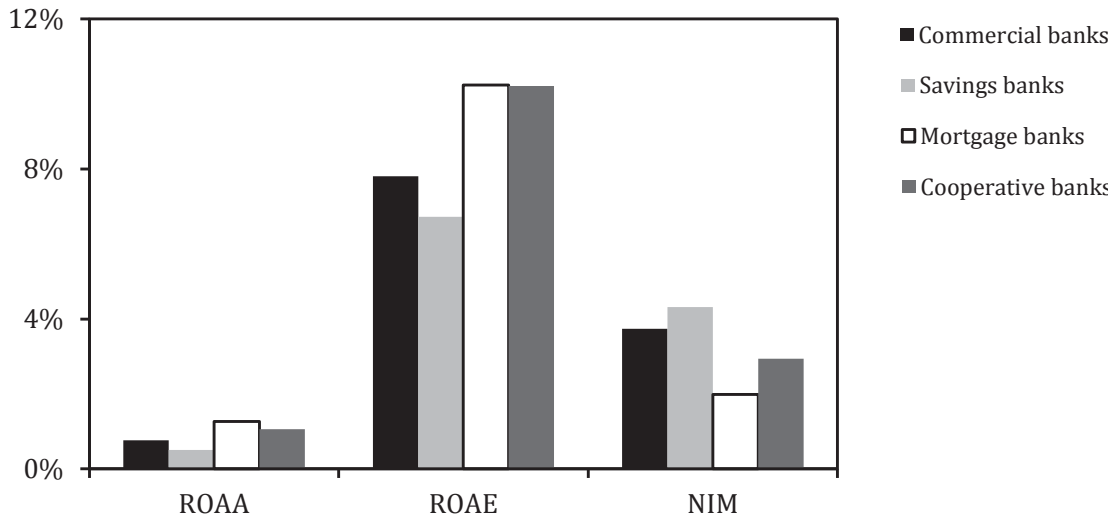

B: Mean ROAE by bank type, evolution over the period 2005 to 2011

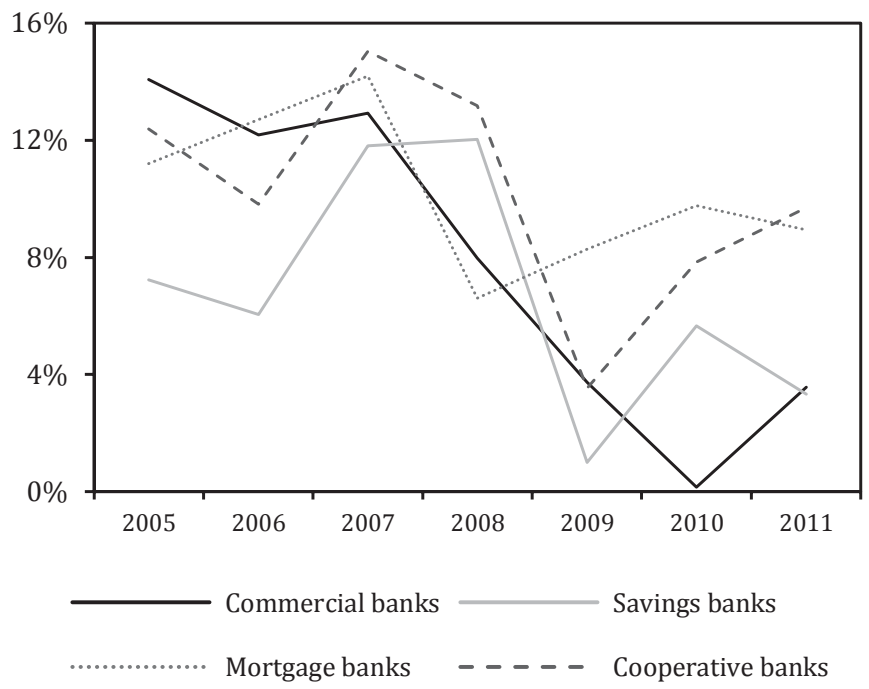

Source: Authors based on the BankScope database

Looking closely at performance of listed and un-/delisted banks, we can see a lot of variability in the sample, mostly among the listed banks. On the other hand, the group of delisted banks is very homogenous in terms of ROAA (see Figure A 1). The relationship between performance measures (ROAA and ROAE, respectively) and the non-performing loans proxy (loan impairment charges) reveals some interesting outliers of the dataset 
such as KBC Bank a.d. Beograd in 2005 where the impairment losses more than doubled from 2004 (see Figure A 2).

The country specific indicators for 2011 are reported in Figure A 3 in the Appendix. Serbia experienced the highest inflation from the analysed countries reaching $11.14 \%$ and also the second largest unemployment rate, outrun by Bosnia and Herzegovina. The lowest GDP growth rate of $-0.37 \%$ was reported by Romania, while the other country with negative growth is Croatia. The Baltic countries, on the other hand, demonstrate a very healthy and promising GDP growth rate. For all three of them, the rate exceeds 5\% per year and they rank on the top followed by Hong Kong and Poland. The Baltic countries are also those most severely hit by the financial crisis, as depicted in Figure 2. In 2009, Latvia's real GDP growth dropped to almost $-18 \%$, and remained in the red in 2010, but reported 5.47\% growth in 2011 .

Figure 2 | Real Annual GDP Growth from 2009 to 2011

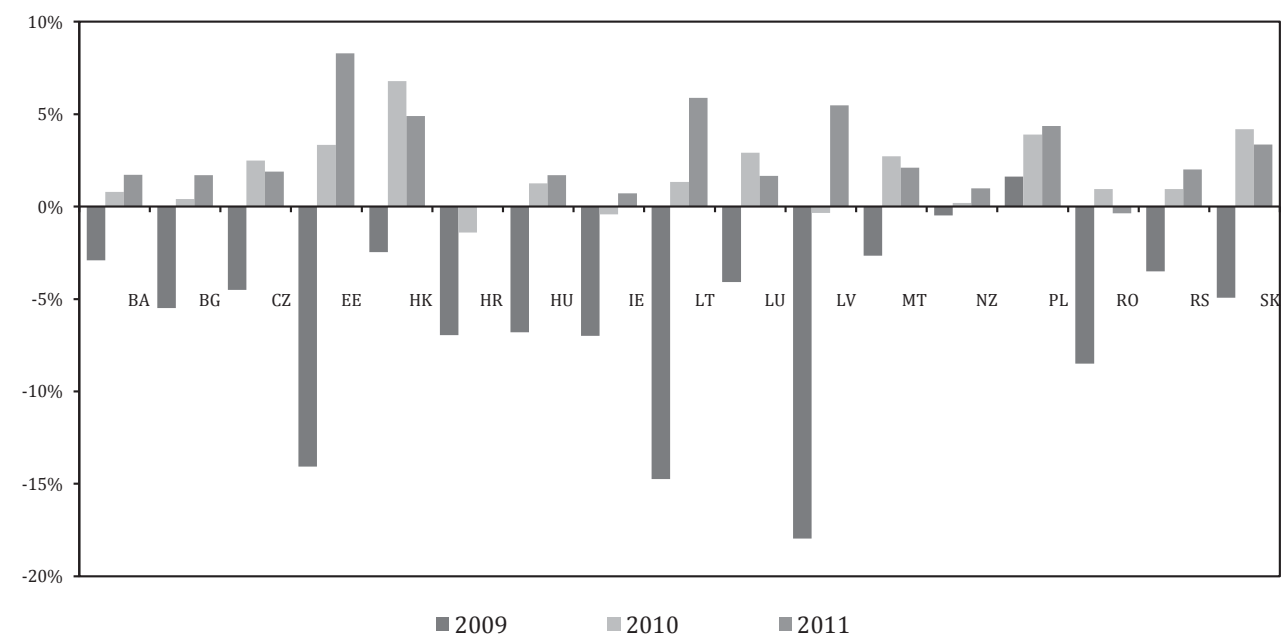

Source: Authors based on World Bank and ECB databases

Figure 3 depicts the banking sector size comparison using first the number of banks within the sector and second banking assets as a fraction of GDP. In terms of number of institutions, Hong Kong surpasses the second ranking Luxembourg by 50 units, however, when comparing the penetration of these two sectors, Luxembourg reports three and a half times larger sector than Hong Kong suggesting the relative smallness of its banks. Similarly, while Romania and Ireland have roughly the same number of credit institutions (42 and 40, respectively), their banking assets shares differ markedly as the Irish system is twelve times larger. The banking assets share also stands out for Malta accounting for $800 \%$ of GDP and thus exceeding twice the sample average in 2011. The lowest relative penetration (measured by banking assets share per credit institution) is reported by Poland, where the value is only $1.27 \%$ (assets as a share of GDP per banking institution), while the sample average for CESEE countries ${ }^{1}$ is $2.73 \%$. For further summary of the variables used, reporting the maximum, minimum, median and $1^{\text {st }}$ and $3^{\text {rd }}$ quartile, see Table A1 in the Appendix.

1 CESEE countries in our sample include Poland, the Czech Republic, Romania, Hungary, Croatia, Serbia, Bulgaria, Slovakia and Bosnia and Herzegovina. 


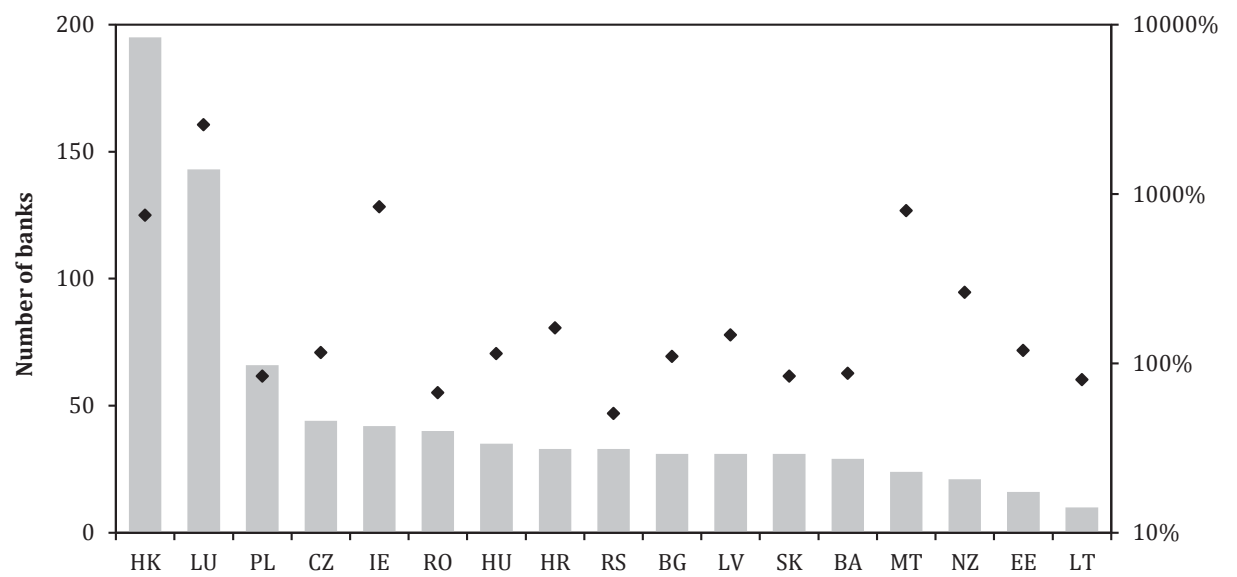

Number of financial institutions (units) - left axis

- Penetration (banking assets to GDP, \%) - right axis

Source: Authors based on World Bank and ECB database

\section{Methodology}

The features of the dataset make it especially suitable for the analysis by means of general method of moments, even though the fixed or random effects approaches are also commonly used in the literature (e.g. Yi et al., 2009). The following paragraphs summarise the generalized method of moments (GMM) method theoretically, culminating with the final specification of the chosen estimating equation.

Generally, the data generating process takes the form of

$$
\begin{gathered}
y_{i t}=\alpha y_{i, t-1}+\mathbf{X}_{i t}^{\prime} \beta+\epsilon_{i t} \\
\epsilon_{i, t}=\mu_{i}+v_{i, t} \\
E\left[\mu_{i}\right]=E\left[v_{i, t}\right]=E\left[\mu_{i} v_{i, t}\right]=0
\end{gathered}
$$

where $i=1, \ldots, N$ is the individual's index and $t=1, \ldots, T$ is a time index. The disturbance term has two components: $\mu_{i}$ stands for the fixed effects and $v_{i, t}$ for the idiosyncratic shock. Estimating Equation 1 via OLS results in its inconsistency due to the dynamic panel bias which is caused by the fact that $y_{i, t-1}$ is correlated with $\mu_{i}$, i.e. the fixed effects error term. If the number of the time periods in the sample $(T)$ was large, the correlation and the endogeneity problem would disappear, however, as this is not the case of our sample, the pooled OLS estimation would be a wrong approach (Wooldridge, 2001).

To deal with the correlation problem, we could firstly address the fixed effects term by applying either least squares dummy variables or a within estimation. However, using the latter the dynamic panel bias remains. The transformation of the lagged dependent variable under within estimation looks as follows

$$
y_{i, t-1}^{*}=y_{i, t-1}-\frac{1}{T-1}\left(y_{i 2}+\ldots+y_{i T}\right)
$$


the transformation of the error term is

$$
v_{i, t}^{*}=v_{i, t}-\frac{1}{T-1}\left(v_{i 2}+\ldots+v_{i T}\right)
$$

and thus the regressor and the error term are still correlated despite the transformation. Two types of transformation are commonly applied to treat endogeneity. Firstly, it is the difference general method of moments (Arellano \& Bond, 1991; Arellano \& Bover, 1995), based on first-difference transformation which when applied to Equation 1 yields

$$
\Delta y_{i, t}=\alpha \Delta y_{i, t-1}+\Delta x_{i, t}^{\prime} \beta+\Delta v_{i, t}
$$

The main disadvantage of this approach is that first-differencing prolongs gaps in case of unbalanced panels. Considering $y_{i, t}$ missing, then $\Delta y_{i, t}$ as well as $\Delta y_{i, t+1}$ would be missing after transformation. More suitable for unbalanced data is the forward orthogonal deviation. The transformation is carried out by subtracting the average of the future observations that are available, which minimizes the potential data loss (Roodman, 2006).

The System GMM (Blundell \& Bond, 1998) is based on the use of instrumental variables that are not correlated with the fixed effects, in order to remove endogeneity, and it makes use of including lagged levels and differences. System GMM also allows for time invariant dummy variables which would be erased if difference GMM was employed.

The estimation equation representing our model for each of the performance measures is as follows:

$$
Y_{i, t}=\alpha Y_{i, t-1}+\beta X_{i, t}+\gamma Z_{t-1}+\delta W_{t}+\mu_{i}+v_{i, t}
$$

where $Y_{i, t} \ldots$ individual banks' performance in year $t$ (dependent variable)

$Y_{i, t-1} \ldots$ individual banks' performance in year $t-1$

$X_{i, t} \quad \ldots$ vector of individual banks' bank-specific variables in year $t$

$Z_{t-1} \quad \ldots$ vector of lagged country-specific variables

$W_{t} \ldots$ vector of banking sector-specific variables

$u_{i} \quad \ldots$ unobserved bank-specific time-invariant effect

$v_{i, t} \quad \ldots$ disturbance term.

\section{Results and Findings}

Table 4 summarises estimation results which are based on the model described in Section 3 while applying orthogonal deviation transformation instead of first differencing, standard errors robust to heteroscedasticity and autocorrelation within cross-sections, adjustments for small samples, and a two-step model. The reported outcome performed best in terms of tested parameters, i.e. the Arellano-Bond AR(1) and AR(2) test, the Hansen test and $F$ test. Here, the LLC test could also be used, for a detailed discussion of DIF-GMM, SYS-GMM and related econometric issues see Janda et al. (2010; 2013). Variables unemp and bond were dropped from the estimation for their correlation and better performance of the model both in terms of diagnostics and variable significance. Following the approach of Heffernan \& Fu (2010) the variable eta was excluded from the instrument set to avoid the endogeneity problem. 


\subsection{Empirical Analysis}

In all cases of dependent variables (ROAA, ROAE and NIM), the F test is highly significant rejecting the hypothesis that the independent variables are jointly insignificant. Similarly, the Hansen test suggests that the model does not suffer from over-identification, and the rule of thumb implying that the number of instruments should not exceed number of groups in the sample is also satisfied. Thus, the GMM estimates are valid. In case of ROAA and NIM, the Arellano-Bond AR(1) test with null hypothesis of no serial autocorrelation in levels is rejected, for all three dependent variables, the AR(2) test with null hypothesis of no second-order serial autocorrelation is not rejected. This result is expected due to the firstdifferenced equation while assuming no serial correlation within the original disturbance term. These tests are important from the GMM estimators' consistency point of view.

Table 4 | Estimation Results (System GMM Model)

\begin{tabular}{|c|c|c|c|c|c|c|}
\hline \multirow[b]{3}{*}{$\begin{array}{l}\text { Independent } \\
\text { variables }\end{array}$} & \multicolumn{6}{|c|}{ Dependent variable } \\
\hline & \multicolumn{2}{|c|}{ ROAA } & \multicolumn{2}{|c|}{ ROAE } & \multicolumn{2}{|r|}{ NIM } \\
\hline & Coefficient & t-statistics & Coefficient & t-statistics & Coefficient & t-statistics \\
\hline constant & 0,014 & 0,51 & $-0,049$ & $-0,13$ & 0,004 & 0,22 \\
\hline I.DV & 0,371 & $4,33^{* * *}$ & 0,060 & 0,67 & 0,741 & $9,85^{* * *}$ \\
\hline ci & $-0,021$ & $-2,93 * * *$ & $-0,121$ & $-2,28^{* *}$ & 0,005 & 1,54 \\
\hline eta & 0,053 & $2,32^{* *}$ & 0,140 & 0,32 & 0,033 & $2,5^{* *}$ \\
\hline la_stf & $-0,005$ & $-0,83$ & 0,003 & 0,07 & $-0,003$ & $-0,91$ \\
\hline IIr_gl & 0,072 & $2 * *$ & $-0,185$ & $-0,56$ & $-0,014$ & $-0,58$ \\
\hline nl_stf & $-0,000$ & 11 & $-0,036$ & $-1,52$ & 0,002 & 1,43 \\
\hline npl & $-0,366$ & $-4,11 * * *$ & $-3,483$ & $-2,23^{* *}$ & 0,016 & 0,29 \\
\hline In_ta & 0,000 & 0,14 & 0,038 & $1,96^{*}$ & 0,002 & $1,83^{*}$ \\
\hline nl_ta & $-0,007$ & $-1,23$ & 0,013 & 0,29 & $-0,004$ & $-1,18$ \\
\hline down & $-0,000$ & $-0,08$ & $-0,064$ & $-1,36$ & $-0,009$ & $-1,95^{*}$ \\
\hline dlist & $-0,002$ & $-0,68$ & 0,016 & 0,28 & 0,003 & 1,28 \\
\hline dcomm & 0,014 & 1,03 & $-0,198$ & $-0,71$ & $-0,011$ & $-0,87$ \\
\hline dcoop & 0,010 & 0,73 & $-0,257$ & $-0,88$ & $-0,017$ & $-1,28$ \\
\hline dsav & 0,020 & 1,14 & $-0,370$ & $-0,9$ & $-0,017$ & $-0,93$ \\
\hline I.infl & $-0,025$ & $-0,75$ & 0,329 & 0,86 & $-0,024$ & $-1,06$ \\
\hline I.gdp & 0,009 & 0,69 & 0,494 & $1,97^{* * *}$ & 0,013 & $1,78^{*}$ \\
\hline hhi & 0 & $-1,53$ & 0 & $-1,54$ & 0 & $-1,5$ \\
\hline nobanks & 0 & $-0,21$ & $-0,001$ & $-1,49$ & 0 & $-2,24^{* *}$ \\
\hline bas & $-0,000$ & $-1,8^{*}$ & $-0,002$ & $-0,47$ & $-0,000$ & $-1,26$ \\
\hline tt & $-0,001$ & $-3,01^{* * *}$ & $-0,006$ & $-0,89$ & $-0,000$ & $-1,51$ \\
\hline \multicolumn{7}{|c|}{ Estimation diagnostics } \\
\hline \multicolumn{2}{|c|}{ Number of observations } & \multicolumn{2}{|c|}{858} & 858 & & 858 \\
\hline Number of gro & & & & 143 & & 143 \\
\hline Observations & group & & & 6 & & 6 \\
\hline F test & & 22, & *** & $8,7^{* * *}$ & & $47,57^{* * *}$ \\
\hline Arellano-Bonc & $R(1)$ & & & $-1,08$ & & $-3,89 * * *$ \\
\hline Arellano-Bonc & $\mathbf{R}(2)$ & & & 0,89 & & $-1,32$ \\
\hline Hansen test & & 119, & & 121,43 & & 107,19 \\
\hline
\end{tabular}

Signif. codes: ‘***'0.01 ${ }^{\prime * * \prime} 0.05^{\prime * \prime} 0.1 " 1$

Source: Authors' computations 
The lagged dependent variable is highly significant for ROAA and NIM and insignificant for ROAE. In all cases, the coefficient is positive. The coefficient of the cost income ratio is significant and negatively signed for all the models excluding NIM. This result suggests that banks with higher operating efficiency tend to perform better. The equity to assets ratio coefficient is significant for ROAA and NIM and for all three types of dependent variables it is positively signed, suggesting that sounder banks' performance is better.

The coefficients of liquidity measures, namely liquid assets and net loans to short term funding, as well as net loans to total assets are insignificant regardless of dependent variable. Moreover, we are unable to specify their effect and draw any reliable inference as the coefficient signs vary. For ROAE and NIM, $l n$ ta is significant bearing a positive sign which is in line of most studies concentrating on advanced economies and attributing the effect of bank size to benefits stemming from economies of scale. For ROAA, the coefficient is also positive though insignificant. In case of ROAA and ROAE, the coefficient of non-performing loans proxy, $n p l$, is highly significant. The estimation result implies that keeping low level of non-performing loans improves the performance which is consistent with our expectations.

Dummy variables included in the regression are mostly insignificant for all types of performance measurements. Thus, the effect of bank listing or bank type is not proven in our sample. The dummy for whether the owner is a credit institution is significant for NIM and has a negative sign (even for ROAA and ROAE), which suggests that the banks owned by a credit institution perform worse overall than those owned by entities such as a government authority, individuals or industrial companies. It is important to bear in mind that the analysed sample contains foreign-owned banks only. Therefore, we may deduce that there is an adverse effect of the parent bank on the performance of its affiliate.

From the country specific variables, the coefficient of lagged GDP growth is significant for ROAE and NIM and overall has a positive sign suggesting that a growing economy has more efficient banking system and thus better performing banks, consistent with our expectations. Similarly, a negative sign was expected for lagged inflation coefficient as is reported in case where ROAA and NIM are the dependent variables.

An influence of concentration of the host banking sector on a foreign-owned bank's performance is not proven as the coefficient is insignificant and its value is very close to zero. The number of banks within the sector is significant for NIM but the value is again very low for all types of performance indicators. The same holds for banking assets where the coefficient is significant solely for ROAA. 
Table 5 | Estimation Results (System Gmm, No Individual Specific Variables)

\begin{tabular}{|c|c|c|c|c|c|c|}
\hline \multirow[b]{3}{*}{$\begin{array}{l}\text { Independent } \\
\text { variables }\end{array}$} & \multicolumn{6}{|c|}{ Dependent variable } \\
\hline & \multicolumn{2}{|c|}{ ROAA } & \multicolumn{2}{|c|}{ ROAE } & \multicolumn{2}{|c|}{ NIM } \\
\hline & Coefficient & t-statistics & Coefficient & t-statistics & Coefficient & t-statistics \\
\hline constant & 2.007 & $3.42^{* * *}$ & 11.902 & 0.9 & -0.1883 & -0.55 \\
\hline I.DV & 0.241 & $3.51^{* * *}$ & 0.345 & $3.67^{* * *}$ & 0.8845 & $24.51^{* * *}$ \\
\hline I.infl & -0.107 & $-2.78^{* * *}$ & -0.972 & $-1.98^{* *}$ & -0.0455 & $-2.65^{* * *}$ \\
\hline l.unemp & -0.006 & -0.36 & -0.265 & -1.37 & 0.0114 & $1.68^{*}$ \\
\hline I.bond & -0.048 & -1.42 & -0.645 & $-1.78^{*}$ & 0.0069 & 0.47 \\
\hline I.gdp & 0.035 & $2.28^{* *}$ & 0.611 & $2.25^{* *}$ & 0.0210 & $3.53^{* * *}$ \\
\hline hhi & 0 & -1.44 & 0 & -0.9 & 0.0000 & $-2.75^{* * *}$ \\
\hline nobanks & 0 & -0.27 & -0.000 & -0.8 & 0.0000 & $-2.33^{* *}$ \\
\hline bas & -0.000 & -0.85 & -0.001 & -0.57 & 0.0000 & -0.02 \\
\hline $\mathrm{Tt}$ & -0.001 & $-3.4^{* * *}$ & -0.006 & -0.89 & 0.0001 & 0.57 \\
\hline \multicolumn{7}{|c|}{ Estimation parameters } \\
\hline \multicolumn{2}{|c|}{ Number of observations } & \multicolumn{2}{|l|}{858} & 858 & \multicolumn{2}{|r|}{858} \\
\hline \multicolumn{2}{|c|}{ Number of groups } & \multicolumn{2}{|l|}{143} & 143 & \multicolumn{2}{|r|}{143} \\
\hline \multicolumn{2}{|c|}{ Observations per group } & \multicolumn{2}{|l|}{6} & 6 & \multicolumn{2}{|r|}{6} \\
\hline \multicolumn{2}{|c|}{ F test } & \multicolumn{2}{|l|}{$13.57^{* * *}$} & $20.6^{* * *}$ & \multicolumn{2}{|r|}{$47.57^{* * *}$} \\
\hline \multicolumn{2}{|c|}{ Arellano-Bond AR(1) } & \multicolumn{2}{|l|}{$-3.31^{* * * *}$} & -1.16 & \multicolumn{2}{|r|}{$-3.99^{* * *}$} \\
\hline \multicolumn{2}{|c|}{ Arellano-Bond AR(2) } & \multicolumn{2}{|l|}{-0.22} & 0.95 & \multicolumn{2}{|r|}{$-1.91^{*}$} \\
\hline Hansen & & 134.72 & & 138.48 & & 31.32 \\
\hline
\end{tabular}

Signif. codes: ${ }^{* * * \prime} 0.01^{\prime * * \prime} 0.05^{\prime * \prime} 0.1 " 1$

Source: Authors' computations

Results of fixed effects model estimation are provided in Appendix (Table A 2) for a robustness check. Clearly, the fixed effects model is not particularly suitable for the data we deal with as it has several limitations: the model does not allow for lagged dependent variable, the estimation of time invariant dummy variables is impossible, biased coefficients arise in case of correlation between lagged dependent variable and regressors. Results, however, suggest the superiority of ROAA as a performance indicator with $R^{2}$ of almost $50 \%$. Both $\mathrm{F}$ tests are significant for all dependent variables confirming that variables are jointly unequal to zero and the presence of individual effects (within groups).

Results of the GMM and FE models differ mostly in significance of each individual variable making lagged GDP growth and HHI coefficient significant in all cases. However, as already stated, the fixed effects estimator is likely biased. To explore the relationship 
between performance and economic fundamentals even more thoroughly, we carry out the estimation of Equation 2 leaving out the vector of individual banks' bank-specific variables. Table 5 reports the results. The significance of some of the variables increased, however, the overall fit of the model is worse compared to the previously reported one. Judging from the results, for the performance of a bank in year $t$, the annual inflation rate and real GDP growth in year $t-1$ matter. Nonetheless, individual characteristics of the bank are also important in explaining its performance. Thus we can conclude that even though some of the economic fundamentals of the host country influence the performance of the foreign-owned banks they are not sufficient to explain its development.

Table 6 summarises the comparison of results with studies carried out by Moon (2009) and Heffernan and $\mathrm{Fu}$ (2010). It is important to bear in mind that these studies concentrate on one banking sector only (Korea and China, respectively) which, moreover, is not dominated by foreign-owned banks. Also, the studies reflect on both foreign- and domestically owned credit institutions operating within the sector.

Table 6 | Comparison of Results

\begin{tabular}{|c|c|c|c|c|c|c|}
\hline & \multicolumn{6}{|c|}{ Dependent variable } \\
\hline & \multicolumn{2}{|c|}{ ROAA } & \multicolumn{2}{|c|}{ ROAE } & \multicolumn{2}{|c|}{ NIM } \\
\hline I.DV & $\checkmark$ & $\checkmark$ & $\checkmark$ & $x$ & $\checkmark$ & $\checkmark$ \\
\hline $\mathrm{Ci}$ & $\checkmark$ & $x$ & $\checkmark$ & $\checkmark$ & $x$ & $x$ \\
\hline Eta & $\checkmark$ & $x$ & $\checkmark$ & $\checkmark$ & $\checkmark$ & $\checkmark$ \\
\hline lastf & $x$ & $\checkmark$ & $\checkmark$ & $x$ & $x$ & $\checkmark$ \\
\hline Ilrgl & $\checkmark$ & $\checkmark$ & $\checkmark$ & $\checkmark$ & $x$ & $x$ \\
\hline nlta & $x$ & $\checkmark$ & $x$ & $\checkmark$ & $x$ & $x$ \\
\hline dlist & $\checkmark$ & $\checkmark$ & $x$ & $\checkmark$ & $x$ & $\checkmark$ \\
\hline l.gdp & $\checkmark$ & $\checkmark$ & $x$ & $x$ & $\checkmark$ & $\checkmark$ \\
\hline hhi & $x$ & $x$ & $\checkmark$ & $\checkmark$ & $\checkmark$ & $x$ \\
\hline
\end{tabular}

$\checkmark$... the results are in accordance with the other studies

$\boldsymbol{x}$... the results differ from other studies

Source: Authors' computations

\subsection{Results Summary}

To conclude, our analysis suggests that foreign-owned banks from countries with overall high foreign ownership share tend to perform better in an environment with growing productivity and low inflation. Therefore, we conclude that the economic fundamentals affect the performance of foreign-owned banks and we thus cannot reject the stated 
hypothesis. However, the analysis has also shown that these factors (macroeconomic indicators) are not sufficient in explaining the determinants of the banks' performance. We find evidence of the fact that more capitalized banks and banks with higher operating efficiency are also better performing in comparison to their peers. Moreover, keeping cost of risk ratio low seems to be crucial for profitability, especially, when measured by return on average assets. Table 7 provides an overview of the effects of indicators on each of the dependent variables.

Table 7 | Effects of Indicators on Each of the Dependent Variables

\begin{tabular}{|l|c|c|c|}
\hline \multicolumn{1}{|c|}{ Dependent variables: } & ROAA & ROAE & NIM \\
\hline Lagged dependent & + & + & + \\
\hline Cost income ratio & - & - & 0 \\
\hline Equity to asset ratio & + & 0 & + \\
\hline Loan loss reserves & + & 0 & 0 \\
\hline Impairment charges & - & - & 0 \\
\hline Inflation & - & - & + \\
\hline Unemployment & 0 & 0 & + \\
\hline Interest rates & 0 & - & 0 \\
\hline GDP growth & + & + & + \\
\hline HHI & 0 & 0 & + \\
\hline Number of banks & 0 & 0 & + \\
\hline Banking assets & 0 & 0 & 0 \\
\hline
\end{tabular}

" + " ... positive correlation; "-“ ... negative correlation; " 0 " ... variable insignificant Source: Authors' computations

\subsection{Further Research Opportunities}

The data analysis revealed further possible areas of research related to the phenomenon of increasing foreign ownership of banks which can be concentrated on. First, individual selected countries can be concentrated on more thoroughly in order to provide cross country comparison. The crucial challenge in this matter is the construction of a dataset with virtually no missing observations of any bank operating within the analysed sector. For some of the countries, this may be a difficult task, but at the same time, a precise estimation is otherwise impossible. In addition to that, new measures of bank performance (such as Economic Value Added) can be further examined and proposed, which again will require substantial data search. Second, as the financial, banking and sovereign crises progress, more data will become available for analysis and thus could be incorporated into the research making the dataset suitable to other methodological approaches. An analysis incorporating structural breaks could be carried out to distinguish the effects 
of the financial meltdown. Third, the fragmentation of the financial sector has recently been getting more attention. ${ }^{2}$ For this reason, further research could provide an analysis in which the bank type will serve as distinguishing factor even though the significance of the banking type was not proven by our up-to-now analysis. Last but not least, the analysis can be applied to countries other than those selected in this paper. The sample could be, for instance, constructed based on foreign-owned banks as listed in BankScope, regardless of the overall share of foreign assets within the banking sector.

\section{Conclusion}

The main motivation for our research was the phenomenon of foreign bank ownership. We tested a hypothesis whether economic fundamentals in the host country influence directly the performance of foreign-owned banks in the host country. Seventeen countries primarily from the Central and Eastern European region were selected for the analysis, namely Bosnia and Herzegovina, Bulgaria, Croatia, the Czech Republic, Estonia, Hong Kong, Hungary, Ireland, Latvia, Lithuania, Luxemburg, Malta, New Zealand, Poland, Romania, Serbia and Slovakia. These countries are characterized by a high share of foreign bank ownership and many of them have a largely concentrated banking sector with top three banks accounting on average for $65 \%$ of the market. We analysed more than 140 domestically operating foreign-owned banks and examined the determinants of their performance in relation to host country conditions over the period of seven years between 2005 and 2011. To our knowledge, we use the largest data set in this respect compared to other researchers.

To analyse the role of the economic fundamentals on the foreign-owned banks, we chose performance measures as the dependent variables, namely ROAA, ROAE and NIM. We included three types of the explanatory variables in the regression: (i) bank specifics, (ii) host country banking sector specifics and (iii) host country specifics. Due to the nature of the dataset the analysis was carried out by means of general method of moments.

The analysis suggested that foreign-owned banks perform better in an environment with growing gross domestic product and low inflation. We can thus conclude that the economic fundamentals affect the performance of foreign-owned banks and cannot reject the stated hypothesis that economic fundamentals of the host country influence the performance of a foreign-owned bank operating in that country. However, the analysis also hinted that in explaining the determinants of the banks' performance the macroeconomic indicators are not sufficient. We found evidence of the fact that more capitalized and operationally efficient banks outperform their peers. Furthermore, a low non-performing loans (cost of risk) ratio is another key factor of foreign-owned banks' performance.

2 We refer to the following recent works dealing with CEE financial markets: Jakubík, Teplý (2011), Černohorská et al. (2012), Heryán, Stavárek (2012), Horváth, Teplý (2013), Rippel et al. (2012) and Stádník (2013), Revenda (2014), Baran, Witzany (2014) or Šútorová, Teplý (2014). 


\section{References}

Albertazzi, U., Gambacorta, L. (2009), "Bank Profitability and the Business Cycle." Journal of Financial Stability, Vol. 5, No. 4, pp. 393-409, http://dx.doi.org/10.1016/j.jfs.2008.10.002

Albertazzi, U., Gambacorta, L. (2010), "Bank Profitability and Taxation." Journal of Banking and Finance, Vol. 34, No. 11, pp. 2801-2810http://dx.doi.org/10.1016/j.jbankfin.2010.06.003

Arellano, M.,Bond, S. (1991), "Some Tests of Specification for Panel Data: Monte Carlo Evidence and an Application to Employment Equation." Review of Economic Studies, Vol. 58, No. 2, pp. 277-297, http://dx.doi.org/10.2307/2297968

Arellano, M., Bover, O. (1995), "Another Look at the Instrumental Variables Estimation of Error-Components Model." Journal of Econometrics, Vol. 68, No. 1, pp. 29-51, http://dx.doi.org/10.1016/0304-4076(94)01642-D

Athanasoglou, P. P., Brissimis, S. N., Delis, M. D. (2008), "Bank Specific, Industry-Specific and Macroeconomic Determinants of Bank Profitability." Journal of International Financial Markets, Institutions and Money, Vol. 18, No. 2, pp. 121-136, http://dx.doi.org/ 10.1016/j.intfin.2006.07.001

Baran, J., Witzany, J. (2014), "Yield Curve Construction after Crisis", Politická Ekonomie, Vol. 62, No. 1, pp. 67-99.

Berger, A. N. (2007a), “Obstacles to a Global Banking System: "Old Europe” versus “New Europe"'.' Journal of Banking and Finance, Vol. 31, No. 7, pp. 1955-1973, http://dx.doi. org/10.1016/j.jbankfin.2007.01.005

Berger, A. N. (2007b), "International Comparisons of Banking Efficiency." Financial Markets, Institutions and Instruments, Vol. 16, No. 3, pp. 119-144.

Berger, A., Humphrey, D. (1997), "Efficiency of Financial Institutions: International Survey and Direction for Future Research." European Journal of Operation Research, Vol. 98, No. 2, pp. 175-212.

Blundell, R., Bond, S. (1998), "Initial Conditions and Moment Restrictions in Dynamic Panel Data Models." Journal of Econometrics, Vol. 87, No. 1, pp. 115-143.

Bonin, J. P., Hasan, I., Wachtel, P. (2005a), “Bank Performance, Efficiency and Ownership in Transition Countries." Journal of Banking and Finance, Vol. 29, No. 1, pp. 31-52., http://dx.doi.org/10.1016/j.jbankfin.2004.06.015

Bonin, J. P., Hasan, I., Wachtel, P. (2005b), “Privatization Matters: Bank Efficiency in Transition Countries." Journal of Banking and Finance, Vol. 29, No. 8-9, pp. 2155-2178, http://dx.doi. org/10.1016/j.jbankfin.2005.03.012

Claessens, S, Demirgüç-Kunt, A., Huizinga, H. (2001), “How Does Foreign Entry Affect Domestic Banking Markets?" Journal of Banking and Finance, Vol. 25, No. 5, pp. 891-911, http://dx.doi.org/10.1016/S0378-4266(00)00102-3

Černohorská, L., Teplý, P. Vrábel, M. (2012), “The VT Index as an Indicator of Market Liquidity Risk in Slovakia." Journal of Economics, Vol. 60, No. 3, pp. 223-238.

Demirgüç-Kunt, A., Huizinga, H. (1999), “Determinants of Commercial Bank Interest Margins and Profitability: Some International Evidence." World Bank Economic Review, Vol. 13, No. 2, pp. 379-408.

European Central Bank (2010), Beyond ROE - How to Measure Bank Performance. Appendix to the Report on EU Banking Structures.

European Central Bank (2010), "Structural Indicators for the EU Banking Sector." Available at: http://www.ecb.int/pub/pdf/other/structralindicatorseubankingsector201001en.pdf [Accessed 30.12.2013]. 
European Central Bank (2013), Press Releases. Available at: http://www.ecb.int/press/pr/ date/2013/html/index.en.html [Accessed 30.12.2013].

Guillen, M. F., Tschoegl, A. E. (2000), “The Internationalization of Retail Banking: The Case of the Spanish Banks in Latin America." Transnational Corporations, Vol. 9, No. 3, pp. 63-98.

Heffernan, S. A., Fu, M. (2010), "Determinants of Financial Performance in Chinese Banking." Applied Financial Economics, Vol. 20, No. 20, pp. 1585-1600.

Heryán, T., Stavárek, D. (2012). "Influence of the Czech Banks on their Foreign Owners'Interest Margin", in Tsounis, N, Vlahvei, A (Eds). International Conference on Applied Economics (ICOAE) at the Swedish University of Agricultural Sciences, Uppsala, Sweden.

Horváth, R. - Teplý, P. (2013), "Risk Management of Building Societies in the Czech Republic," Journal of Economics, Vol. 61, No. 1, pp. 24-46.

Iršová, Z., Havránek, T. (2010), "Measuring Bank Efficiency: A Meta-Regression Analysis." Prague Economic Papers, Vol. 19, No. 10, pp. 307-328.

Jakubík, P., Teplý, P. (2011), "The JT Index as an Indicator of Financial Stability of Corporate sector." Prague Economic Papers, Vol. 20, No. 2, pp. 157-176.

Janda, K., Michalikova, E., Potacelova, V. (2010), "Gravity and Fiscal Models of Government Support of Export Credit in the Czech Republic." (In Czech: “Gravitační a fiskální modely státní podpory exportnich úvěrů v České republice") Politická ekonomie, Vol. 58, No. 3, pp. 305-325.

Janda, K., Michalikova, E., Skuhrovec, J. (2013), “Credit Support for Export: Robust Evidence from the Czech Republic." The World Economy, Vol. 12, No. 36, pp. 1588-1610.

Mejstř́ík, M., Pečená, M., Teplý, P. (2014), Banking in theory and practice. Prague: Karolinum Press.

Miklaszewska, E., Mikolajczyk, K. (2012), Foreign Banks in CEE-5: Impact of Foreign Governance on Bank Performance, Paper presented at 2012 Wolpertinger Conference, University of Wales, Bangor.

Miller, S., Parkhe, A. (2002), "Is There a Liability of Foreignness in Global Banking? An Empirical Test of banks' X-efficiency." Strategic Management Journal, Vol. 23, No. 1, pp. 55-75.

Moon, W. (2009), Foreign Ownership and Performance of Banks: The Case of Korea. Available at: https://editorialexpress.com/cgi-bin/conference/download.cgi?db_name=FEMES09\&paper_id=540 [Accessed 30.12.2013].

Popov, A., Udell, G. F. (2010), “Cross-Border Banking and the International Transmission of Financial Distress during the Crisis of 2007-2008." European Central Bank ,Working Paper No 1203.

Revenda, Z. (2014), "Assistance to troubled banks - theory, reality and monetary implications" (in Czech: Pomoc ohroženým bankám - teorie, realita a měnové dopady"). Politická ekonomie, Vol. 62, No. 2, pp. 270-288.

Roodman, D. (2006), "How to Do xtabond2: An Introduction to "Difference" and "System" GMM in Stata." Center for Global Development Working Paper Number 103.

Rippel, M., Suchánková, L, Teplý, P. (2012), "The Role of Insurance in Operational Risk Mitigation - A Case Study." Politická ekonomie, Vol. 60, No. 4, pp. 523-35.

Stádník, B. (2013). "Market Price Forecasting and Profitability - How to Tame Random Walk?" Verslas: Teorija ir Praktika / Business: Theory and Practice, Vol. 14, No. 2, pp. 166-176.

Stavárek, D. (2005), "Estimation of Factors Influencing Efficiency of Banks in New Member States before Joining the European Union." Ekonomický časopis Vol. 53, No. 6, pp. 593-610.

Stavárek, D. (2006), "Banking Efficiency in the Context of European Integration. Eastern European Economics." Vol. 44, No. 4, pp. 5-31. 
Šútorová, B., Teplý, P. (2014), “EU Banks' Profitability and Risk Adjustment Decisions under Basel III.“ Journal of Economics/Ekonomický časopis, Vol. 62, No. 7, pp. 667-692.

To, H. M., Tripe, D. (2002), “Factors Influencing the Performance of Foreign-Owned Banks in New Zealand." Journal of International Financial Markets, Institutions and Money, Vol. 12, No. 4, pp. 341-357.

Tripe, D., McIntyre, M. L., Wood, J.G. (2009), “How do Retail Depositors Perceive ForeignOwned Bank Risk: Evidence from New Zealand." Risk Management. Vol. 11, No. 2, pp. 135-153.

Williams, B. (1998), "Factors Affecting the Performance of Foreign-Owned Banks in Australia: A Cross-Sectional Study." Journal of Banking and Finance, Vol. 22, No. 2, pp. 197-219, http://dx.doi.org/10.1016/S0378-4266(97)00054-X

Wooldridge, J. (2001), Econometric Analysis of Cross Section and Panel Data. MIT Press.

World Bank (2012), Bank Nonperforming Loans to Total Gross Loans (\%), Available at: http://data.worldbank.org/indicator/FB.AST.NPER.ZS [Accessed 30.12.2013].

World Bank (2013), Bank Capital to Assets Ratio (\%), Available at: http://data.worldbank.org/ indicator/FB.BNK.CAPA.ZS [Accessed 30.12.2013].

Yi, I., Miller, S. M., Jeon, Y. (2009), "The Effects of Increased Foreign Ownership on Korean Domestic Banks." The Journal of Korean Economy, Vol. 10, No. 1, pp. 127-150.

Zaheer, S., Mosakowski, E. (1997), "The Dynamics of the Liability of Foreignness: A Global Study of Survival in Financial Services." Strategic Management Journal, Vol. 18, No. 6, pp. 439-464.

\section{Appendix}

Figure A 1 | Performance of Banks Based on Listing (Minimum and Maximum throughout the Sample, 2005-2011)

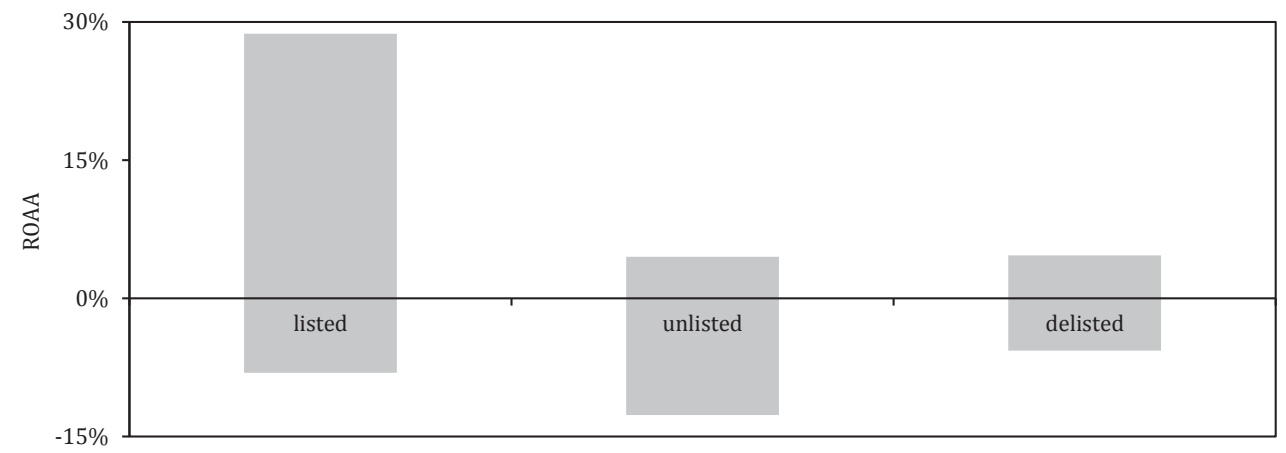

Source: Authors based on BankScope database 
Figure A 2 | Scatter Plot: Performance and Loan Impairment Charges (2005-2011)
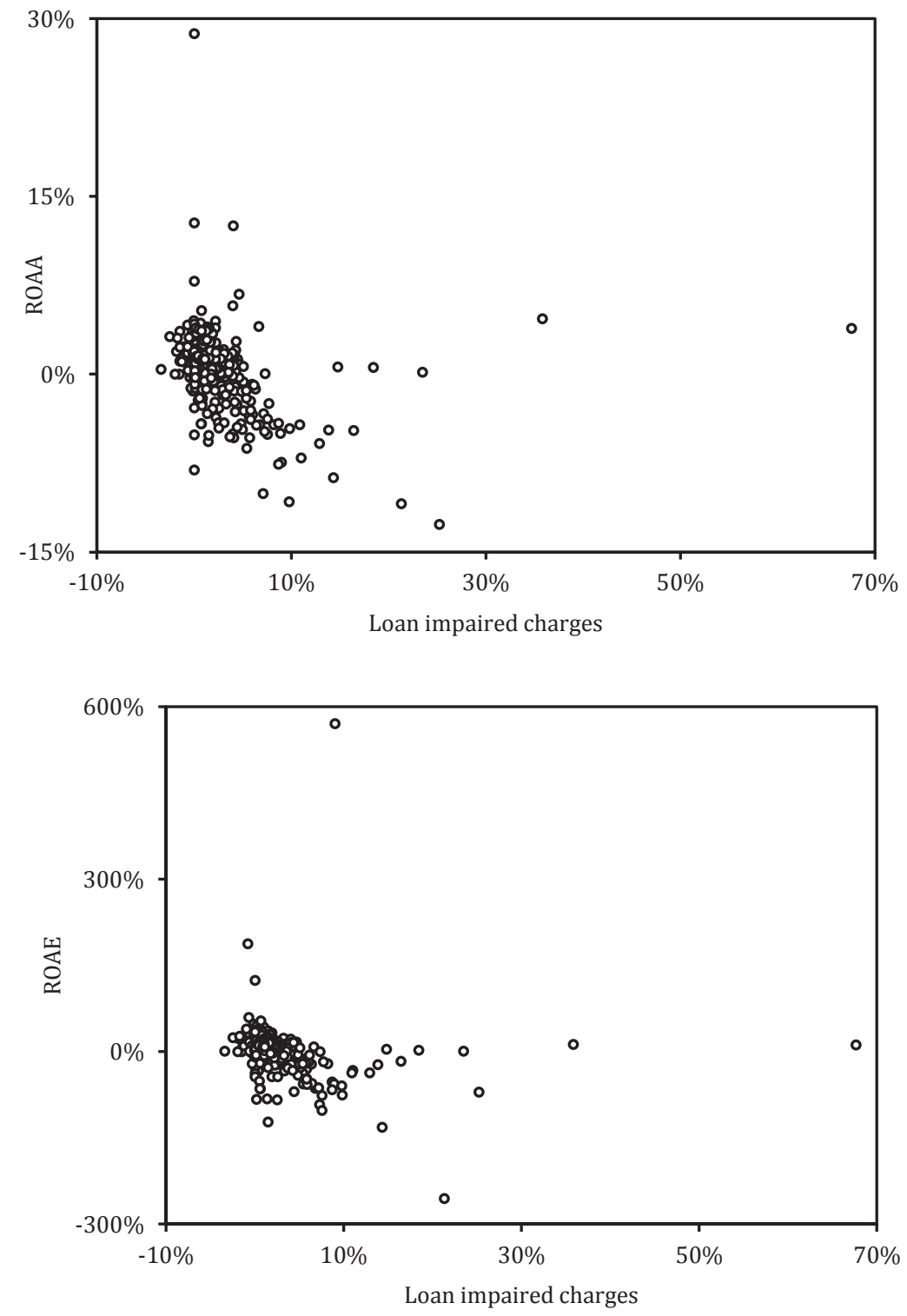

Source: Authors based on BankScope database 
Figure A 3 | Macroeconomic Conditions in 2011

\section{A: Real annual GDP growth}

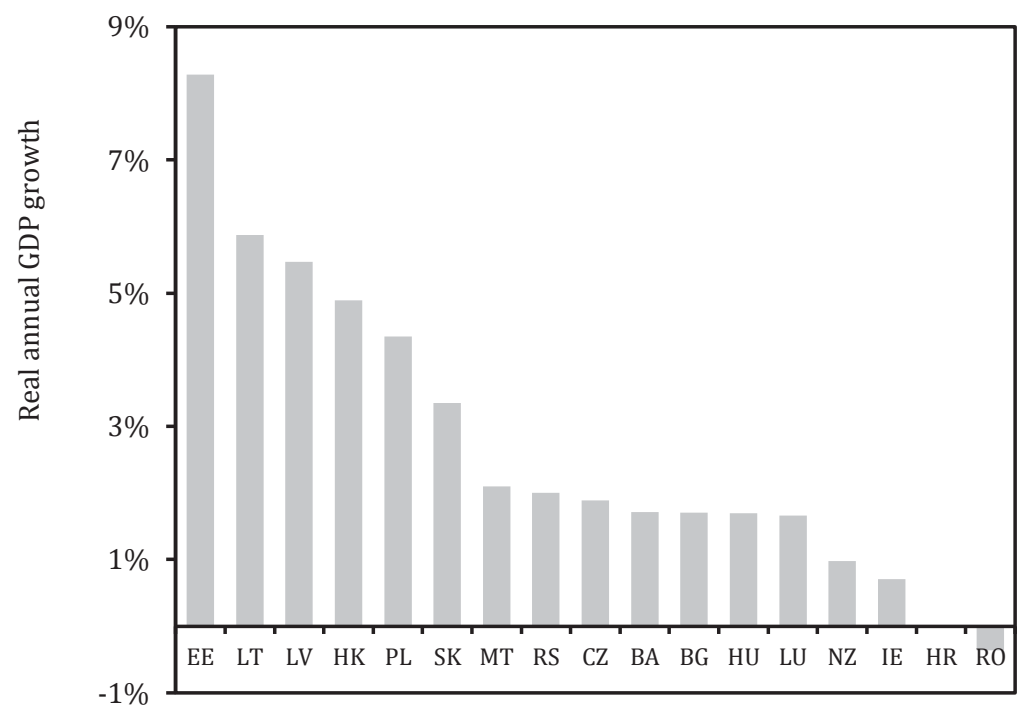

\section{B: Annual unemployment rate}

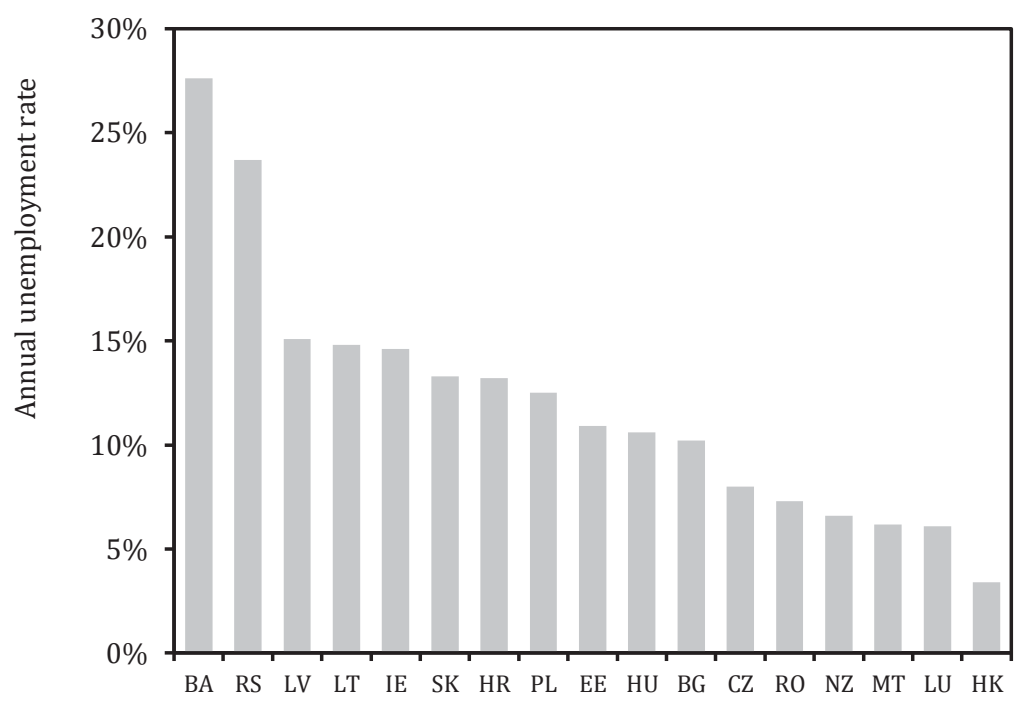




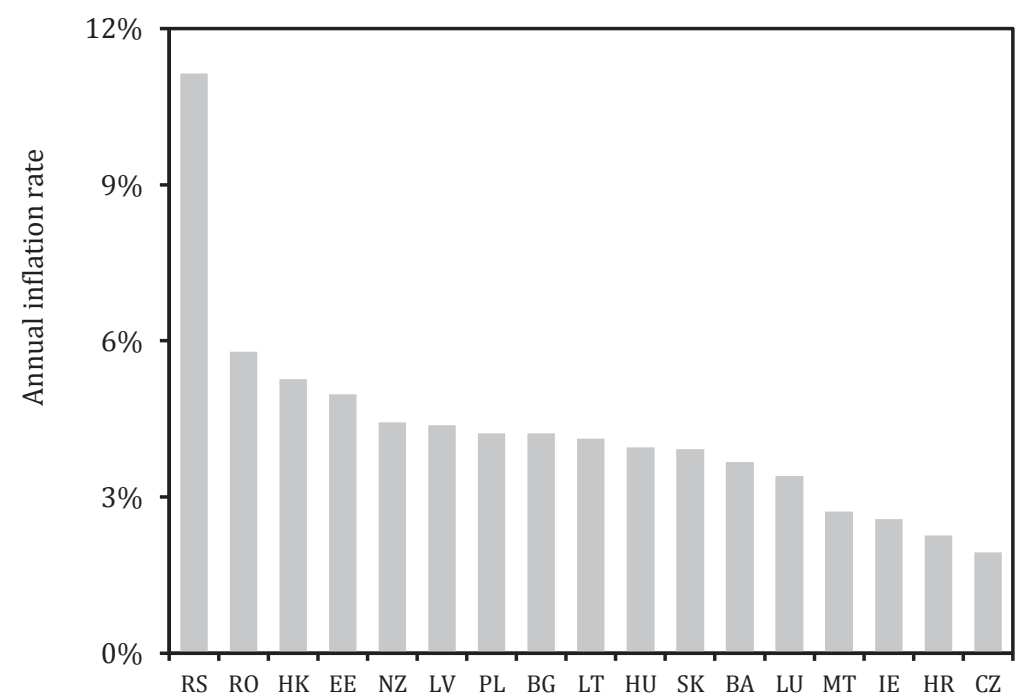

D: 10-year government bond yield

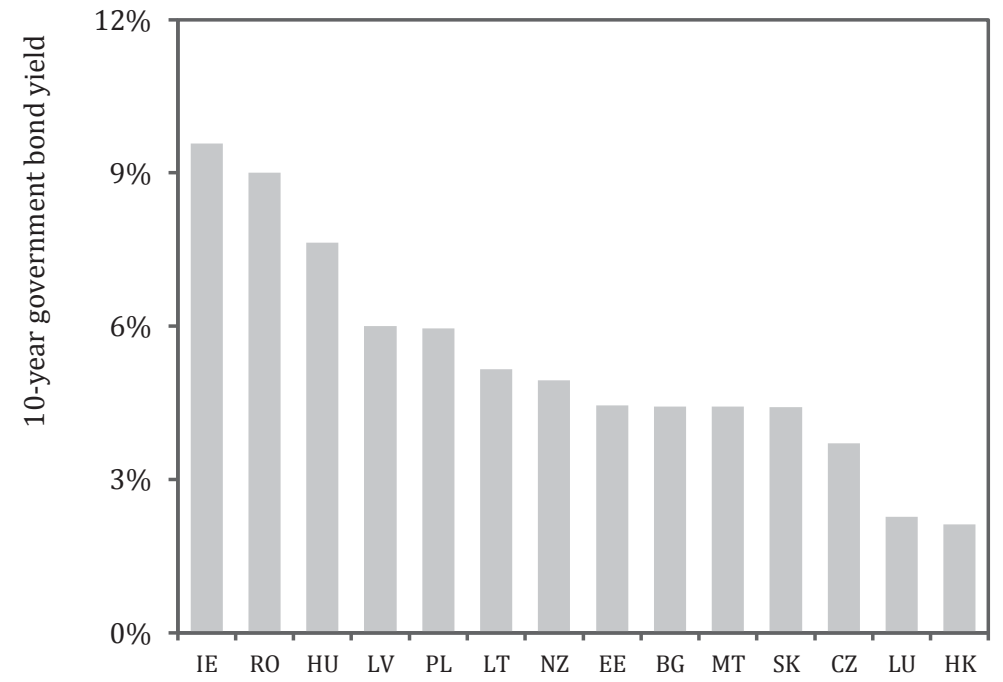

Source: Authors based on World Bank and ECB database 
Table A 1 | Summary Statistics of Variables

\begin{tabular}{|l|c|c|c|c|c|}
\hline & min & $\mathbf{1 s t}$ quartile & median & 3rd quartile & max \\
\hline bas & $44,00 \%$ & $75,00 \%$ & $106,00 \%$ & $169,00 \%$ & $3225,00 \%$ \\
\hline bond & $0,00 \%$ & $0,00 \%$ & $4,20 \%$ & $5,60 \%$ & $15,50 \%$ \\
\hline ci & $0,00 \%$ & $47,70 \%$ & $58,90 \%$ & $72,80 \%$ & $418,80 \%$ \\
\hline eta & $-2,40 \%$ & $7,40 \%$ & $9,80 \%$ & $13,60 \%$ & $80,60 \%$ \\
\hline gdp & $-17,90 \%$ & $1,00 \%$ & $4,20 \%$ & $6,40 \%$ & $12,20 \%$ \\
\hline hhi & 410 & 710 & 1205 & 1544 & 8822 \\
\hline infl & $-4,40 \%$ & $2,30 \%$ & $3,80 \%$ & $6,10 \%$ & $16,10 \%$ \\
\hline la_stf & $-6,50 \%$ & $17,60 \%$ & $28,80 \%$ & $42,50 \%$ & $496,50 \%$ \\
\hline IIr_gl & $0,00 \%$ & $0,90 \%$ & $2,60 \%$ & $5,10 \%$ & $67,80 \%$ \\
\hline In_ta & 9,44 & 13,02 & 14,66 & 16,08 & 20,14 \\
\hline nim & $-0,60 \%$ & $2,10 \%$ & $3,20 \%$ & $4,60 \%$ & $16,30 \%$ \\
\hline nl_stf & $0,00 \%$ & $60,30 \%$ & $74,50 \%$ & $89,50 \%$ & $597,10 \%$ \\
\hline nl_ta & $6,70 \%$ & $45,40 \%$ & $58,90 \%$ & $70,30 \%$ & $255,60 \%$ \\
\hline nobanks & 10 & 30 & 35 & 64 & 204 \\
\hline npl & $-3,40 \%$ & $0,20 \%$ & $0,60 \%$ & $1,50 \%$ & $67,60 \%$ \\
\hline roaa & $-12,60 \%$ & $0,40 \%$ & $1,00 \%$ & $1,50 \%$ & $28,70 \%$ \\
\hline roae & $-255,50 \%$ & $3,00 \%$ & $9,50 \%$ & $16,20 \%$ & $570,20 \%$ \\
\hline unemp & $3,40 \%$ & $5,80 \%$ & $8,20 \%$ & $13,30 \%$ & $31,80 \%$ \\
\hline
\end{tabular}

Source: Authors based on BankScope database and World Bank 
Table A 2 | Estimation Results (Fixed Effects Model)

\begin{tabular}{|c|c|c|c|c|c|c|}
\hline \multirow[b]{3}{*}{$\begin{array}{l}\text { Independent } \\
\text { variables }\end{array}$} & \multicolumn{6}{|c|}{ Dependent variable } \\
\hline & \multicolumn{2}{|c|}{ ROAA } & \multicolumn{2}{|c|}{ ROAE } & \multicolumn{2}{|c|}{ NIM } \\
\hline & Coefficient & t-statistics & Coefficient & t-statistics & Coefficient & t-statistics \\
\hline constant & 0,027 & 0,89 & $-0,102$ & $-0,15$ & 0,086 & $3,62 * * *$ \\
\hline ci & $-0,018$ & $-10,29 * * *$ & $-0,132$ & $-3,19 * * *$ & 0,000 & 0,17 \\
\hline eta & 0,058 & $5,54 * * *$ & 0,043 & 0,18 & 0,054 & $6,45 * * *$ \\
\hline la_stf & $-0,003$ & $-1,27$ & 0,004 & 0,09 & $-0,002$ & $-1,18$ \\
\hline IIr_gl & $-0,079$ & $-4,71 * * *$ & $-0,976$ & $-2,53^{* *}$ & $-0,021$ & $-1,58$ \\
\hline nl_stf & $-0,000$ & $-0,19$ & $-0,002$ & $-0,06$ & $-0,000$ & $-0,15$ \\
\hline npl & $-0,282$ & $-13,97 * * *$ & $-2,372$ & $-5,1^{* * *}$ & 0,020 & 1,23 \\
\hline In_ta & $-0,002$ & $-1,19$ & 0,011 & 0,26 & $-0,005$ & $-3,24 * * *$ \\
\hline nl_ta & 0,005 & $1,73^{*}$ & 0,059 & 0,98 & 0,002 & 0,79 \\
\hline I.infl & $-0,059$ & $-3,54 * * *$ & $-0,200$ & $-0,52$ & 0,016 & 1,23 \\
\hline I.gdp & 0,044 & $4,86 * * *$ & 0,620 & $2,96 * * *$ & 0,037 & $5,9 * * *$ \\
\hline hhi & 0 & $-2,39 * *$ & $-0,000$ & $-2,08 * *$ & 0 & $-1,31$ \\
\hline nobanks & 0,000 & $2,29 * *$ & 0,003 & 0,69 & 0,000 & 1,23 \\
\hline bas & 0 & 0,03 & 0,008 & 0,52 & $-0,000$ & $-0,78$ \\
\hline \multicolumn{7}{|c|}{ Estimation diagnostics } \\
\hline \multicolumn{2}{|c|}{ Number of observations } & \multicolumn{2}{|c|}{858} & 858 & \multicolumn{2}{|c|}{858} \\
\hline \multicolumn{2}{|c|}{ Number of groups } & \multicolumn{2}{|c|}{143} & 143 & \multicolumn{2}{|c|}{143} \\
\hline \multicolumn{2}{|c|}{ Observations per group } & \multicolumn{2}{|c|}{6} & 6 & \multicolumn{2}{|r|}{6} \\
\hline \multicolumn{2}{|l|}{ R2 } & \multicolumn{2}{|c|}{0,499} & 0,141 & \multicolumn{2}{|c|}{0,203} \\
\hline \multicolumn{2}{|l|}{ F test (1) } & \multicolumn{2}{|c|}{$53,86^{* * *}$} & $8,89^{* * *}$ & \multicolumn{2}{|c|}{$13,72^{* * *}$} \\
\hline \multicolumn{2}{|l|}{ F test (2) } & \multicolumn{2}{|c|}{$3,49^{* * * *}$} & $1,87^{* * *}$ & \multicolumn{2}{|c|}{$10,6^{* * *}$} \\
\hline
\end{tabular}

Signif. codes: ${ }^{\prime * * * \prime} 0.01^{1 * * \prime} 0.05^{* * \prime} 0.1^{\prime \prime} 1$

Source: Authors' computations 


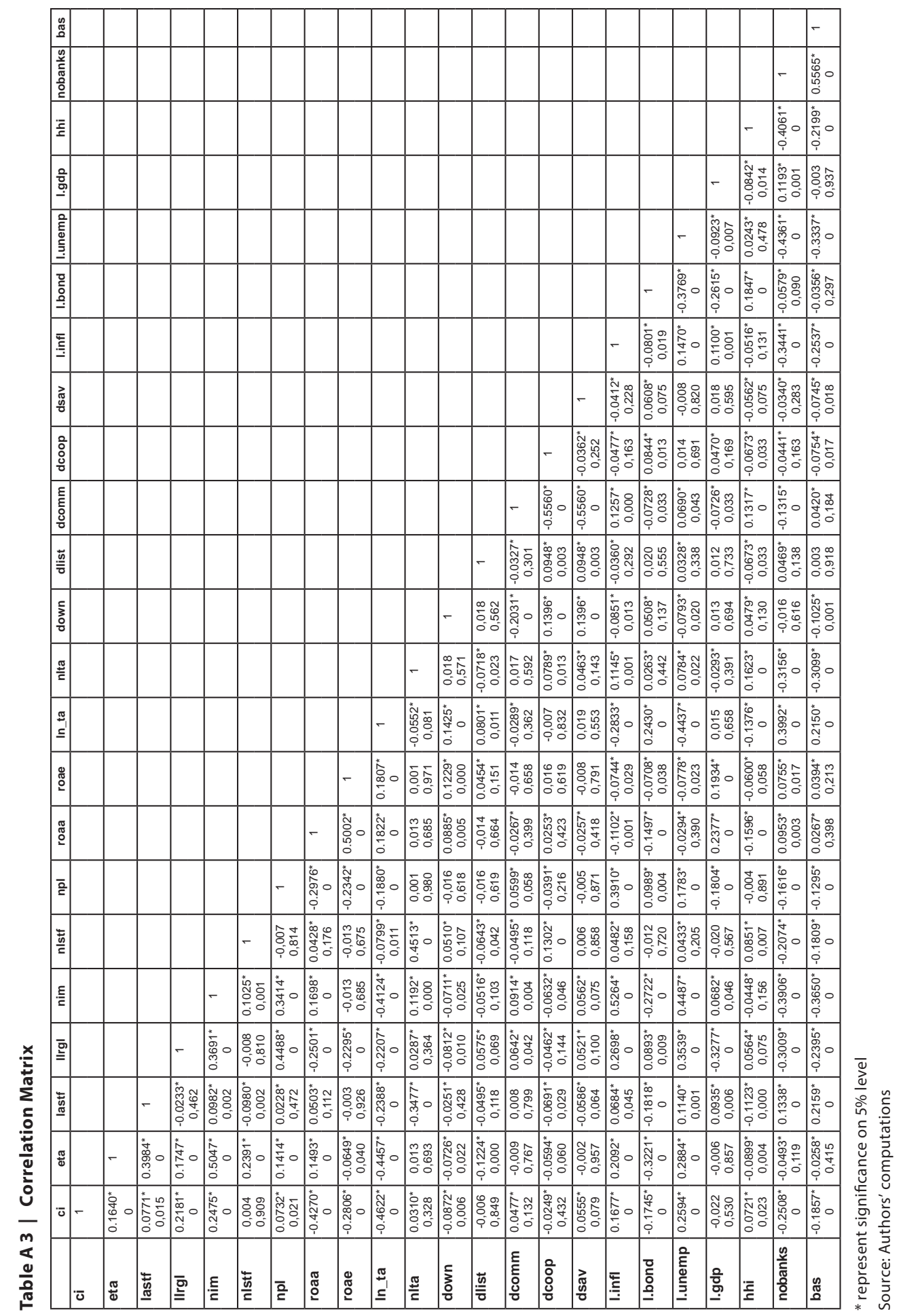

